\section{Grain Moisture of Maize Hybrids in Different Maturity Groups at Various Harvesting Dates}

\author{
Lajos Csaba Marton - Tamás Árendás - \\ Péter Bónis
}

Agricultural Research Institute of the Hungarian Academy of Sciences, Martonvásár

\section{SUMMARY}

The experiments were designed to determine the extent to which late harvesting helped to achieve low grain moisture content. The grain moisture contents of 24 hybrids from each of four different maturity groups were recorded during the last decade of September and the first decade of November over a period of three years (1999-2001).

The data indicated that late harvesting led to a substantially smaller difference between the hybrids. While in late September the difference between the grain moisture content of the earliest (FAO 200) and latest (FAO 500) hybrids was 8.9\%, this value dropped to $1.5 \%$ over the average of three years when measurements were made in early November. With the exception of the earliest group, the grain moisture content in all the maturity groups declined during October. The later the hybrid, the greater the decline.

This change in the grain moisture content during October exhibited a considerable year effect. When the weather in October was warm, with little rain, the decrease was greater, while in cool, wet years the grain moisture content declined to a lesser extent, or in some cases even increased.

\section{INTRODUCTION}

If maize is sown as a forecrop for winter cereals, only hybrids with very short vegetation periods can be grown due to the early (September) harvest (Marton et al., 1999). If the maize is followed by a spring-sown crop, however, other considerations can be given priority in choosing the vegetation period and harvesting date.

Due to the increase in drying costs, there is a real demand for maize hybrids with rapid drying down, which can be harvested with a low grain moisture content. In order to exploit the genetic potential latent in the hybrids and to achieve the lowest possible grain moisture, maize is harvested at an ever later date except on areas where winter wheat is to be sown. The results of previous experiments (Cavalieri and Smith, 1985; Crane et al., 1959; Cross and Kabir, 1989; Hallauer and Russell, 1961) indicated that drying down continued, to an extent depending on the genotype, even after physiological maturity, thus proving the advantage of late harvesting.

The demand for a lower grain moisture content at harvest is also reflected in official trials, in changes in the grain moisture data and in the methods used to calculate FAO numbers. These FAO numbers were calculated on the basis of the number of days required to reach a grain moisture content of $34-36 \%$ in the sixties, 28-30\% in the seventies (Váczi, 1972; Menyhért, 1979), and $28 \%$ or later $25 \%$ in the $80 \mathrm{~s}$. In the 90 s the FAO number was often calculated on the basis of grain moisture contents of less than $20 \%$ (Neduczáné, 1998; Marton et al., 1999).

The following paper discusses changes in the grain moisture content of hybrids with various vegetation periods when harvested at different dates, compared with the earliest (September) harvesting date.

\section{MATERIALS AND METHODS}

The grain moisture contents of 24 hybrids in each of 4 maturity groups, including official standards, registered Martonvásár hybrids and other hybrids, were studied in Martonvásár in the last 10 days of September and the first 10 days of November in the years 1999-2001. The experiment was set up each year in four replications and the maize was sown at the optimum date. Grain moisture was determined after drying in a drying cabinet, in two replications in September and in four replications in November. The data were evaluated using analysis of variance according to Sváb (1981).

\section{RESULTS AND DISCUSSION}

Averaged over the 96 hybrids examined in the experiment, the results indicated that later harvesting had a favourable effect in reducing grain moisture. At the later harvesting date the grain moisture content of the hybrids was almost $4 \%$ lower than in late September (Table 1). In different years the trends in grain moisture content showed considerable variation. The greatest reduction $(7.56 \%)$ was observed in 2001, but there was also a considerable decrease in grain moisture in 1999 (5.64\%). This difference in grain moisture was equivalent to a 10 $15 \%$ reduction in the drying costs per hectare, so it had a substantial economic effect. It is thus clear that if the weather in October is warm and dry, the grain moisture declines by several per cent. It should be noted, however, that in 2000, when October was cool and wet, the average grain moisture content of the tested hybrids was greater in November than in late September (Table 1). 
Trends in grain moisture content in late September and early November

Martonvásár, 1999-2001

\begin{tabular}{|c|r|r|r|r|}
\hline Year & September & November & Difference & LSD $_{5 \%}$ \\
\hline 1999 & 26.62 & 20.98 & 5.64 & -1.33 \\
\hline 2000 & 16.25 & 17.58 & 0.41 \\
\hline 2001 & 24.06 & 16.50 & 0.31 \\
\hline Mean & 22.31 & 18.35 & 0.42 \\
\hline
\end{tabular}

A separate analysis of the changes in grain moisture in individual maturity groups revealed that the grain moisture of later hybrids declined substantially as the result of later harvesting (Table 2). The grain moisture in November was $7.2 \%$ lower for the FAO 500 hybrids, $5.8 \%$ for the FAO 400 hybrids and $2.9 \%$ lower for the FAO 300 group than in late September, while that of the FAO 200 hybrids did not decrease during this period but exhibited a slight, $0.15 \%$ increase.

Grain moisture contents of maize hybrids during the last 10 days of September and the first 10 days of November Martonvásár, 1999-2001

\begin{tabular}{|c|r|r|r|r|}
\hline Maturity group & \multicolumn{2}{|c|}{$\begin{array}{c}\text { Last decade of } \\
\text { September }\end{array}$} & $\begin{array}{c}\text { First decade of } \\
\text { November }\end{array}$ & Difference \\
\hline FAO 200 & 17.43 & 17.58 & -0.15 & 2.94 \\
\hline FAO 300 & 20.93 & 17.99 & 18.53 & 0.32 \\
\hline FAO 400 & 24.57 & 19.11 & 0.32 \\
\hline FAO 500 & 26.31 & 0.32 \\
\hline
\end{tabular}

On the basis of the data it can be seen that, averaged over three years, the grain moisture of hybrids in the earliest maturity group dropped to below $20 \%$ by the end of September and was no lower in early November. At the same time, the grain moisture of hybrids in later maturity groups continued to decline during October. It was clear that the later the hybrid, or rather the higher the grain moisture content in late September, the greater the reduction in grain moisture in the course of October. Thanks to this trend, there was a reduction in the difference between the grain moisture contents of hybrids in different maturity groups in the case of late harvesting. While in late September the difference between the grain moisture contents of the earliest and latest gropus was $8.9 \%$, averaged over the three years, this difference had dropped to $1.5 \%$ by the beginning of November.

As the result of this tendency for the values to even out, grain moisture data originating from late harvests are unsuitable for the determination of maturity groups. It can also be concluded that, in the case of optimum sowing date, hybrids with longer vegetation periods (FAO 500, FAO 400) should be selected if later harvesting is planned.

\section{REFERENCES}

Cavalieri, A. J.-Smith, O. S. (1985): Grain filling and field drying of a set of maize hybrids released from 1930 to 1982. Crop Sci., 25. 856-860.

Crane, P. L.-Miles, S. R.-Newman, J. E. (1959): Factors associated with varietal differences in rate of field drying in corn. Agron J., 51. 318-320.

Cross, H. Z.-Kabir, K. M. (1989): Evaluation of field dry-down rates in early maize. Crop Sci., 29. 54-58.

Hallauer, A. R.-Russell, W. A. (1961): Effects of selected weather factors on grain moisture reduction from silking to physiologic maturity. Agron. J., 225-229.

Marton, L. Cs.-Berzsenyi, Z.-Szundy, T.-Árendás, T.-Bónis, P. (1999): Különböző tenyészidejü kukoricahibridek termőképességének és szemnedvességének összehasonlító értékelése. Tiszántúli Mezőgazdasági Tudományos Napok, Debrecen, 1999. október 28-29. (Eds: Ruzsányi, L.-Lesznyák Mné-Jávor, A.), 85-89.

Menyhért, Z. (1979): Különböző tenyészidejü kukoricák. In: Kukoricáról termelőknek. Ed.: Menyhért, Z. Mezőgazdasági Kiadó, Budapest, 271.

Neduczáné Krékity, M. (1998): Szemes- és silókukorica fajták bejelentésének, vizsgálatának és minősítésének rendszere. OMMI, Budapest, 13.

Sváb, J. (1981): Biometriai módszerek a kutatásban. Mezőgazdasági Kiadó, Budapest, 557.

Váczi, D. (1972): A kukorica. In: OMFI kiadványa, Budapest, 132. 